Role of agricultural engineering in FARM MACHINERY AND POWER environmental and sustainable development

for the valley and delta areas: 1125- 1140

\title{
EFFECT OF MINIMUM TILLAGE ON CONSERVATION OF PRECISE LEVELED SOIL TO PRODUCE SOME WINTER CROPS AFTER RICE
}

\author{
Dr Bahnas, O. T.
}

\begin{abstract}
\end{abstract}
During 2006 winter season, this study was carried out at Kalabsho Region, El-Dakhlia Governorate, to find out the effect of minimum tillage on conservation of precise leveled soil to produce some winter crops after rice harvest. During 2006 summer season, before rice planting, the soil was leveled using laser control equipment. After rice harvest, two experiments were established for planting clover, representing the flat planting and sugar beet, representing the ridge planting. Each experiment was designed statistically as a split plots with three replications. The main plots were located for the precision land leveling treatment levels of 0, 0.01, 0.02 and 0.03\% slope, comparing with the traditional leveling using the hydraulic scraper and the sub plots were devoted for the tillage methods levels of minimum tillage (chisel plough one pass) and conventional tillage (chisel plough 2 passes(, comparing with no-till. The obtained results could be concluded as follows:

1. The minimum tillage at the precision land leveling slope of $0.02 \%$ achieved the more desirable soil characteristics (the moderate soil mean weight diameter of $50 \mathrm{~mm}$, the higher soil moisture content of $22.85 \%$, the lower soil bulk density of $1.30 \mathrm{~g} / \mathrm{cm}^{3}$, the lower soil penetration resistance of $1.21 \mathrm{MPa}$ and the higher available soil macronutrients concentration of 30,14 and 318 ppm for $N, P$ and $K$, respectively).

2. The minimum tillage at the precision land leveling slope of $0.02 \%$ accomplished higher degree of soil topography conservation and recorded the lower difference between the highest and the lowest spots.

3. The minimum tillage at the precision land leveling slope of $0.02 \%$ achieved the higher beet yield of $28.65 \mathrm{Mg} / \mathrm{fed}$ with a sucrose yield of $22.04 \%$ and complemented the higher total dry $(14 \%$ moisture

\footnotetext{
*Senior Researcher at the Ag. Eng. Res. Inst. (AEnRI), Giza.
} 
content d.b.) clover yield of $17.10 \mathrm{Mg} /$ fed $(2.12,3.32,4.04,4.36$ and

$2.87 \mathrm{Mg} / \mathrm{fed}$ for $1^{\text {st }}, 2^{\text {nd }}, 3^{\text {rd }}, 4^{\text {th }}$ and $5^{\text {th }}$ cuts, respectively).

So, it is recommended to apply the minimum tillage, especially with the ridge planting, after rice harvest to conserve the precise leveled soil.

\section{INTRODUCTION}

T $\mathrm{n}$ Egypt, rice is the most predominant cultivated summer crop. It is the most important staple food after wheat and one of the major export agricultural commodity. Rice is considered as one of the highly irrigation demand crops (Abu-Zaid, 1995 and Mourad et al., 2003). Rice is cultivated as a fully irrigated crop with standing water. Water is a major constituent of plant tissue, a reagent in chemical reactions and is essential for cell enlargement through increasing turgor pressure. Rice plant can transpire the potential rate even when soil moisture content is around the field capacity (Nour et al., 1994 and Nour et al., 1997).

The subsequent irrigation and the excess water due to the misuse of irrigation application contribute to the ground water shallow aquifers, causing several acute problems i.e. nutrient leaching, raising ground water table .... etc. Consequently, such problems are negatively affecting the next cultivated crop yield and reducing fertilizer and water use efficiency (Abd El-Aal et al., 2005).

The precision land leveling allows maintenance of a uniform water depth within the rice field, increases water use efficiency by maintaining shallow water depths up to panicle initiation stage, helping in better seedling establishment which helps in term for early tillering. In addition, it achieves better utilization of nutrients by managing uniform depth of water through out the field. Also, it enhances the oxygen diffusion is more uniformity. Furthermore, it minimizes the deep percolation of water to a certain extent (El-Sahrigi et al., 2002, El-Raie et al., 2003 and ElRaie et al., 2004).

The Egyptian farmers are commonly accustomed to plant the winter crops after rice without tillage. Abd El-Mageed (1989) and El-Sayed and Ismail (1994) found that no-till achieved disagreeable soil properties, comparing with some tillage methods. 
So, there is increasing interest in minimum tillage as a proper method of reducing crop production costs and improving soil conditions (El-Banna et al., 1987, El-Nakib and Fouad 1990and Abd El-WAhab, 1994).

This study aimed to identify the effect of minimum tillage on conservation of précised leveled soil to produce some winter crops after rice.

\section{MATERIAL AND METHODS}

\section{Experimental Procedure:}

\section{Experimental site and soil characteristics:}

During 2006 winter season, this study was established in reclaimed sandy soil at Kalabsho Region, El-Dakhlia Governorate. The previous crop was rice. During 2006 summer season, at the same experimental site the study of Bahnas et al. (2009) was established. Before rice planting, the soil was leveled using laser control equipment at $0,0.01,0.02$ and $0.03 \%$, comparing with the traditional leveling using the hydraulic scraper.

According to the standard procedures as cited by El-Serafy and ElGhamry (2006), tables (1) and (2) demonstrate the soil mechanical analysis and some soil characteristics of the experimental site.

Table (1): Soil mechanical analysis of the experimental site.

\begin{tabular}{|c|c|c|c|c|}
\hline \multicolumn{3}{|c|}{ Sand, \% } & \multirow{2}{*}{ Silt, \% } & \multirow{2}{*}{ Clay, \% } \\
\cline { 1 - 5 } Coarse, \% & Fine, \% & Total, \% & & \\
\hline 82.40 & 2.20 & 84.60 & 7.60 & 7.80 \\
\hline
\end{tabular}

Table (2): Some soil characteristics of the experimental site.

\begin{tabular}{|l|c|c|c|c|c|c|}
\hline \multirow{2}{*}{ Soil leveling degree } & \multirow{2}{*}{$\begin{array}{c}\text { Moisture } \\
\text { content, \% }\end{array}$} & $\begin{array}{c}\text { Bulk } \\
\text { density, } \\
\text { (d.b.) }\end{array}$ & $\begin{array}{l}\text { Penetration } \\
\text { g/cm }\end{array}$ & $\begin{array}{c}\text { resistance, } \\
\text { MPa }\end{array}$ & \multicolumn{3}{|c|}{$\begin{array}{c}\text { Available } \\
\text { macronutrients, } \\
\text { ppm }\end{array}$} \\
\cline { 5 - 8 } & & & & $\mathrm{N}$ & $\mathrm{P}$ & $\mathrm{K}$ \\
\hline 0 slope & 18.35 & 1.60 & 1.21 & 21.55 & 10.20 & 303.80 \\
\hline $0.01 \%$ slope & 18.65 & 1.52 & 1.19 & 22.15 & 10.85 & 306.55 \\
\hline $0.02 \%$ slope & 19.88 & 1.40 & 1.16 & 23.74 & 11.25 & 310.00 \\
\hline $0.03 \%$ slope & 18.94 & 1.47 & 1.17 & 22.80 & 10.95 & 308.95 \\
\hline Traditional leveling & 17.47 & 1.65 & 1.23 & 19.00 & 9.75 & 300.85 \\
\hline
\end{tabular}

2. Soil topography: 
Soil topography was studied in terms of surveying grid. According to Mc Clung et al. (1985), the experimental field survey was determined and shown in Figure (1).

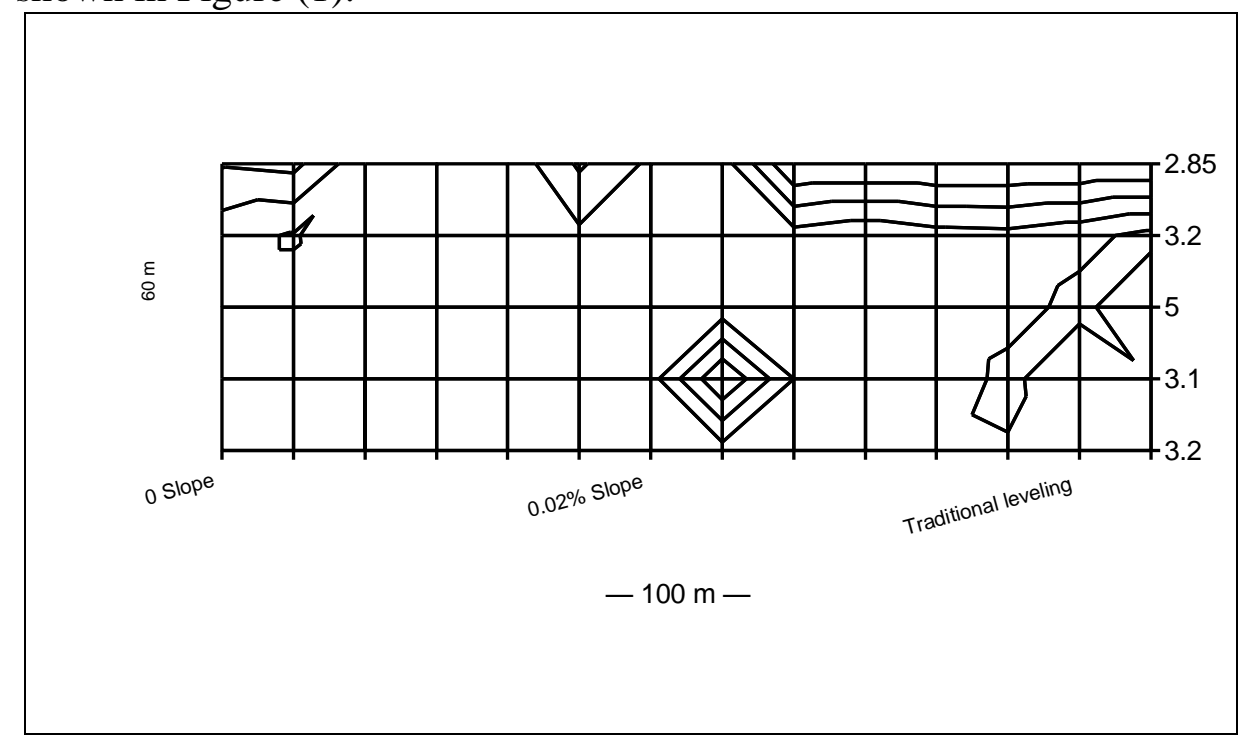

Fig. (1): Schematic diagram of the experimental site grid survey.

\section{Treatments and statistical design:}

After rice harvest, the experimental area of 1.50 fed $(100 \times 60 \mathrm{~m})$ was bisected into two equal portions to establish two experiments as follows:

1. Flat planting experiment: The selected clover seeds of Giza 10 variety with a rate of $17 \mathrm{Kg} / \mathrm{fed}$ were drilled using a mounted seed drill of 21 rows with $0.15 \mathrm{~m}$ row spacing.

2. Ridge planting experiment: The selected sugar beet seeds of Top variety with a rate of $2.00 \mathrm{Kg} / \mathrm{fed}$ were planted using a pneumatic planter at row spacing of $0.60 \mathrm{~m}$ with $0.20 \mathrm{~m}$ hill spacing at the same ridge. Five ridges were attached to the planter to accomplish planting and ridging at the same time.

Each one of the experiments was designed statistically as a split plots with three replications. The main plots were located for the precision land leveling treatment levels of $0,0.01,0.02$ and $0.03 \%$ slope, comparing with the traditional leveling using the hydraulic scraper and the sub plots were devoted for the tillage methods of minimum tillage 
(chisel plough one pass) and traditional tillage (chisel plough 2 passes), comparing with no-till.

\section{Measurements:}

\section{Soil characteristics:}

At harvest, the soil mean weight diameter was determined as cited by Kepner et al. (1982), the soil moisture content (d.b.), the soil bulk density and the soil penetration resistance were determined according to ASAE (1992) and the available soil macronutrients concentration is determined as cited by El-Serafy and El-Ghamry (2006).

\section{Soil topography:}

At harvest, according to Mc Clung et al. (1985), the soil topography is studied in terms of surveying grid and standard deviation.

\section{Sugar beet and clover crop yield:}

At harvest, for each treatment, an area of $1 \mathrm{~m}^{2}$ was taken randomly to determine sugar beet and clover crop yield. This procedure was replicated three times. The mean value of beet yield was calculated and sucrose yield was estimated colorimetrically on a lead acetate extract of fresh macerated as cited by Blakeney and Mutton (1980). The mean value of clover yield at each one of five cuts was calculated on basis of $14 \%$ moisture content (d.b.).

\section{Statistical Analysis:}

SAS computer software package was used to employ the analysis of variance test and the LSD tests for clover and sugar beet crop yield data.

\section{Regression and Correlation Analysis:}

Microsoft Excel 2007 computer software was used to carry out the simple regression and correlation analysis to represent the effect of the precision land leveling slope levels on clover and sugar beet crop yield under the tillage treatment levels.

\section{RESULTS AND DISCUSSION}

\section{Soil Characteristics:}


Figures (2) and (3) exhibits that the minimum tillage at $0.02 \%$ precision land leveling slope after sugar beet harvest complemented more desirable soil characteristics among the other treatments. It achieved the moderate soil mean weight diameter of $50 \mathrm{~mm}$, the higher soil moisture content of $22.85 \%$, the lower soil bulk density of $1.30 \mathrm{~g} / \mathrm{cm}^{3}$, the lower soil penetration resistance of $1.21 \mathrm{Mpa}$ and the higher available soil macronutrients concentration of 30,14 and $318 \mathrm{ppm}$ for $\mathrm{N}, \mathrm{P}$ and $\mathrm{K}$, respectively. This result may be illustrated that the minimum tillage beaks the soil aggregates, creating soil particles of smaller pore spaces with grater free pore spaces per unit of soil volume. This phenomenon leads to lowering the mechanical connections between the soil particles. So, the soil resistance to the moisture diffusion decreases. Then, the soil bulk density and the soil penetration resistance decrease. Consequently, the soil aeration increases that enhances the soil organic matter mineralization, releasing more amount of the available macronutrients.

On the contrary, the conventional tillage consummated lower soil meen weight diameter value due to the tillage intensity which encloses the soil pore spaces of higher surface tension that increases the soil bonding forces, leading to pore spaces increment, that create an aggregated structure of the higher values of soil bulk density and soil penetration resistance. Consequently, the soil nutrients release diminishes.

Furthermore, the lower degree of soil pulverization that related with the no-till which associated with the lower soil moisture content as a result of soil drying causes higher soil cohesion between the soil particles, leading to diminishing the pore spaces volume, causing the degradation in soil characteristics.

Data display that planting both sugar beet and clover improves the soil characteristics. As the sugar beet grows, it transfuses and penetrates the soil, creating a disconnected structure of the desirable characteristics. In addition, the ridge planting decreases the water percolation as a result of distributing the soil surface. Whilst, the growth of clover as a legumes is fixing atmospheric nitrogen and involving the excess uptake of nutrient cations over anions from soil solution. This results in the net efflux of 
$\mathrm{H} 3 \mathrm{O}+$ ions from plant roots into the rhizosphere, resulting in the accumulation of soil organic matter.

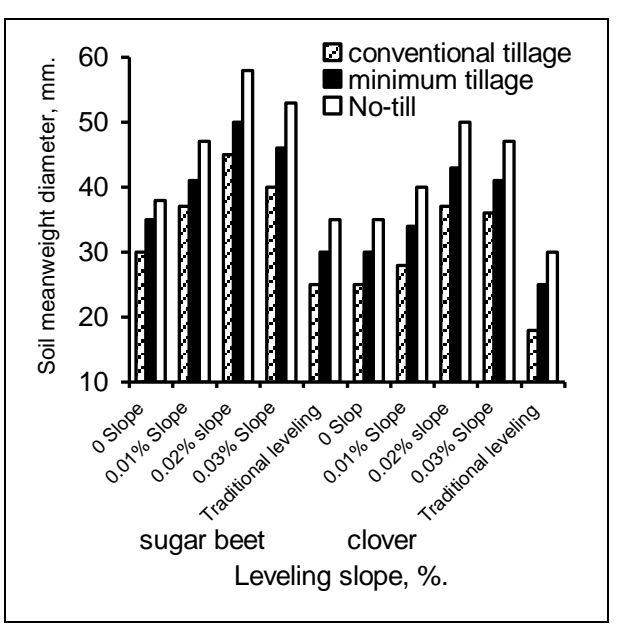

a. Mean weight diameter (MWD).

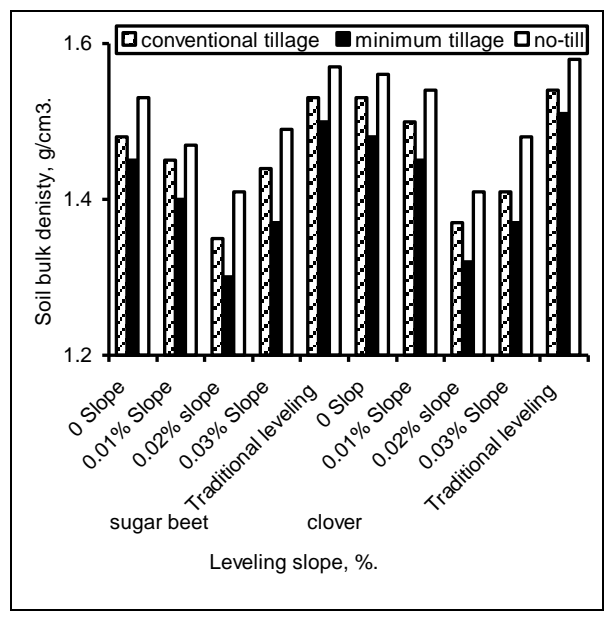

c. Bulk density.

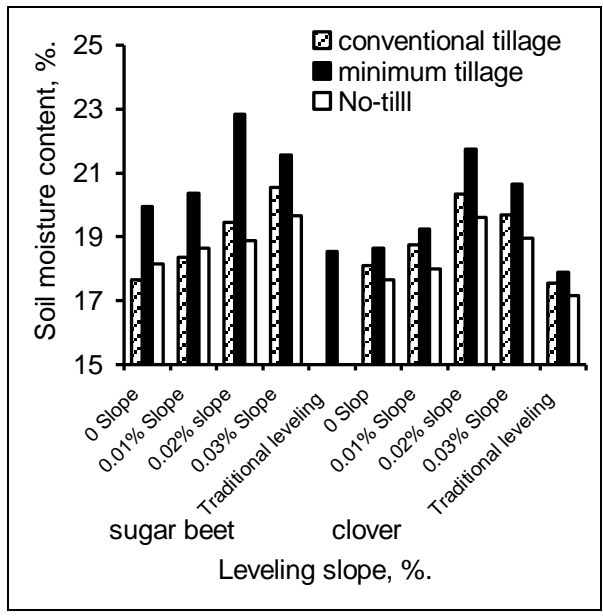

b. Moisture content.

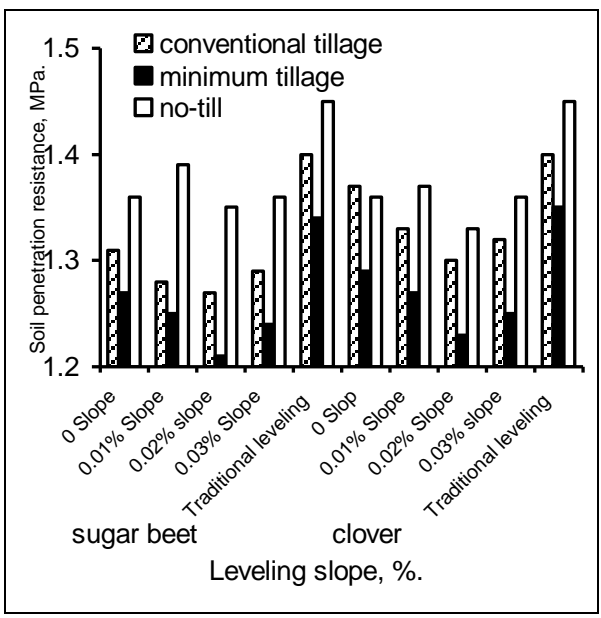

d. Penetration resistance.

Fig. (2): Effect of minimum tillage on some soil characteristics. 


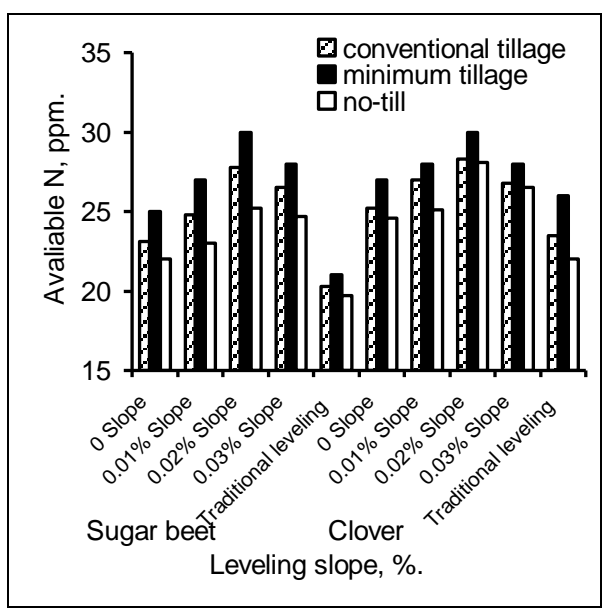

a. Available soil N.

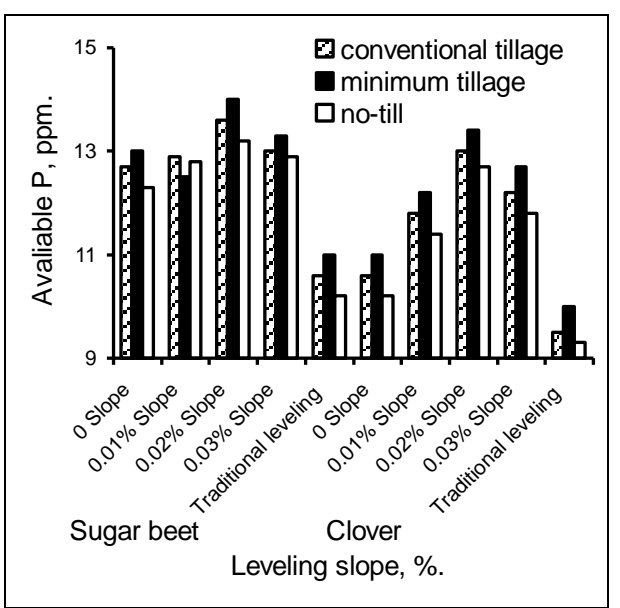

b. Available soil P.

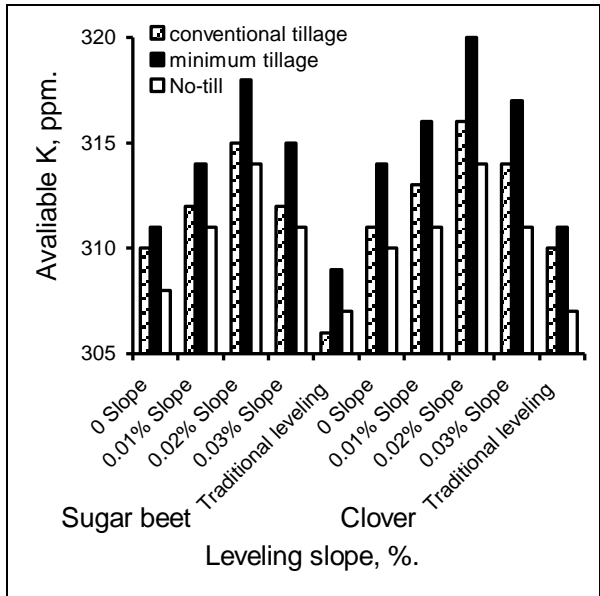

c. Available soil K.

Fig. (3): Effect of minimum tillage on available soil macronutrients concentration.

\section{Soil Topography:}

Figure (4) reveals the significant effect of the minimum tillage on the soil topography conservation, especially at $0.02 \%$ precision land leveling slope after sugar beet harvest. The minimum tillage after sugar beet harvest at precision land leveling slope of $0,0.01,0.02$ and $0.03 \%$ and traditional leveling recorded the lower value of the difference between the highest and the lowest spots of $0.80,0.20,0.20,0.40$ and $1.50 \mathrm{~m}$, with an average level for the total spot readings of 3.22, 3.20, 3.04, 3.15 and $3.45 \mathrm{~m}$ and a standard deviation of $\pm 0.3526, \pm 0.2386, \pm 0.1285, \pm$ 0.2646 and 


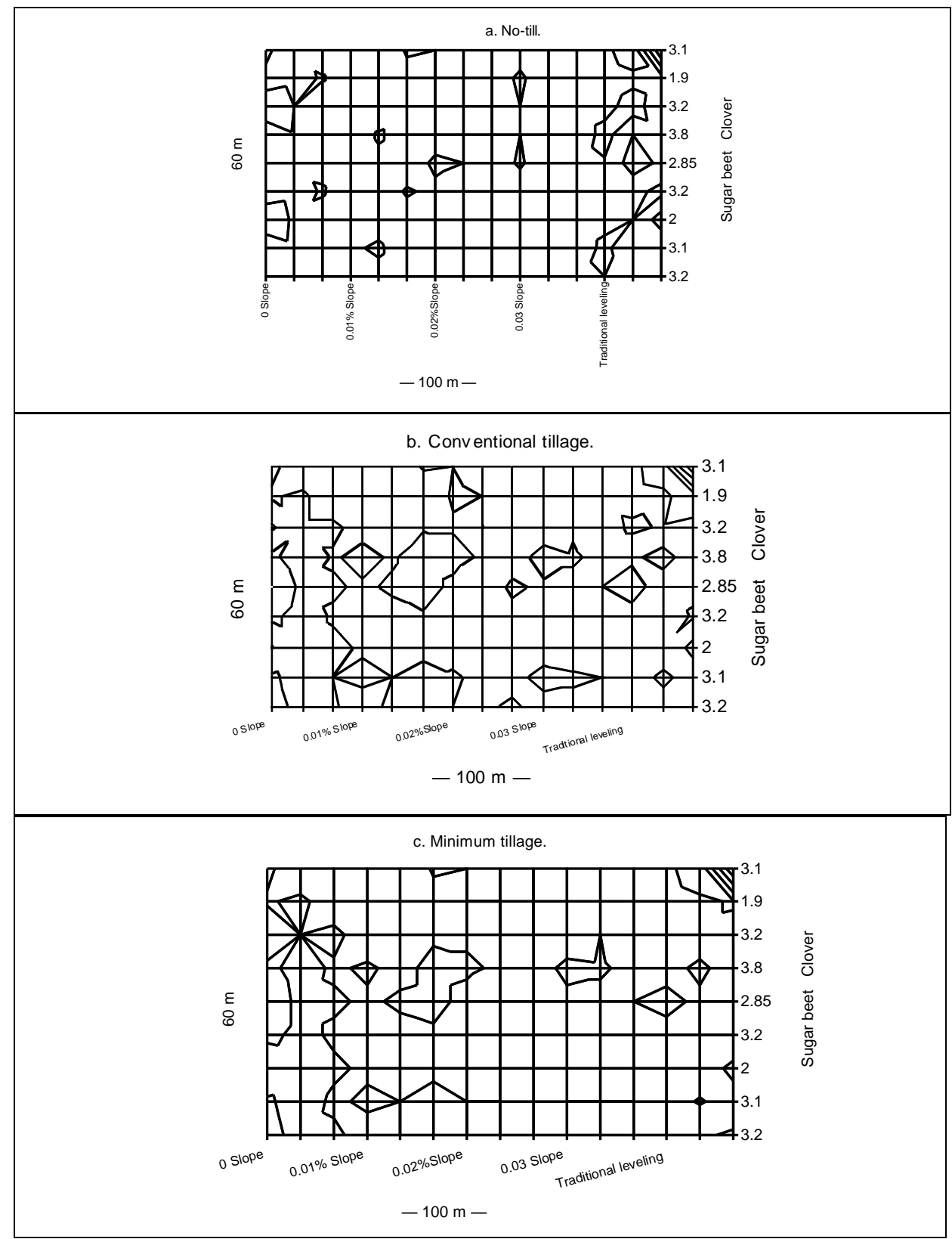

Fig. (4): Schematic diagram of the experimental field grid survey after sugar beet and clover harvest. 
\pm 0.4521 , respectively. In addition, no-till after clover harvest at precision land leveling slope of $0,0.01,0.02$ and $0.03 \%$ and traditional leveling accomplished the higher value of the difference between the highest and the lowest spots of 1.60, 1.10, 0.80, 1.80 and $1.90 \mathrm{~m}$, with an average level for the total spot readings of $3.50,3.42,3.40,3.47$ and 3.87 $\mathrm{m}$ and a standard deviation of $\pm 0.5881, \pm 0.3470, \pm 0.2796, \pm 0.3351$ and \pm 0.5638 , respectively.

This finding could be explained that the minimum tillage creates a proper disturbed surface which lowers the soil curette. In addition, this proper seed bed facilitates both the application and removal of soil water for irrigation and drainage. These practices can result in high efficiency of irrigation water application, uniform distribution of irrigation water and elimination of tail water. The irrigation water penetrated more rapidly in this proper seedbed than in other cases. When application of water continued the soil water content become greater than other cases. The rapid infiltration of water to depth appeared to be mainly due to the greater continuity of channels in soil which are not disturbed by either the intensive tillage or no-till. Also, the ridge planting achieved more soil surface conservation than the flat planting due to the corrugated surface as a result of distributing the soil surface into ridges which minimizes the soil sweeping.

\section{Crop Yield:}

Figures (5) and (6) indicate that the effect of tillage methods on sugar beet and clover crop yield is to a large degree attributable to the difference in soil characteristics. The figures demonstrate the significant effect of minimum tillage on crop yield among the other treatments. It achieved the higher beet yield of $28.65 \mathrm{Mg} / \mathrm{fed}$ with a sucrose yield of $22.04 \%$ and complemented the higher total dry clover yield of 17.10 $\mathrm{Mg} /$ fed $\left(2.12,3.32,4.04,4.36\right.$ and $2.87 \mathrm{Mg} /$ fed for $1^{\text {st }}, 2^{\text {nd }}, 3^{\text {rd }}, 4^{\text {th }}$ and $5^{\text {th }}$ cuts, respectively). This finding is attributed to the more favorable soil characteristics of moderate clod diameter with larger pore spaces. This environment is desirable for root growth and oxygen diffusion. 


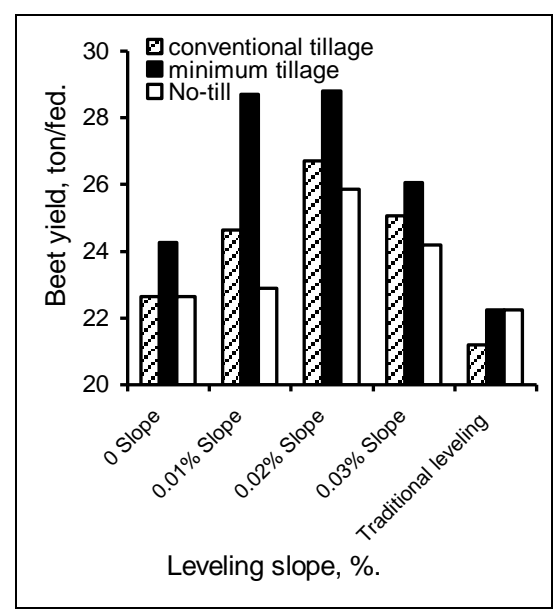

a. Beet.

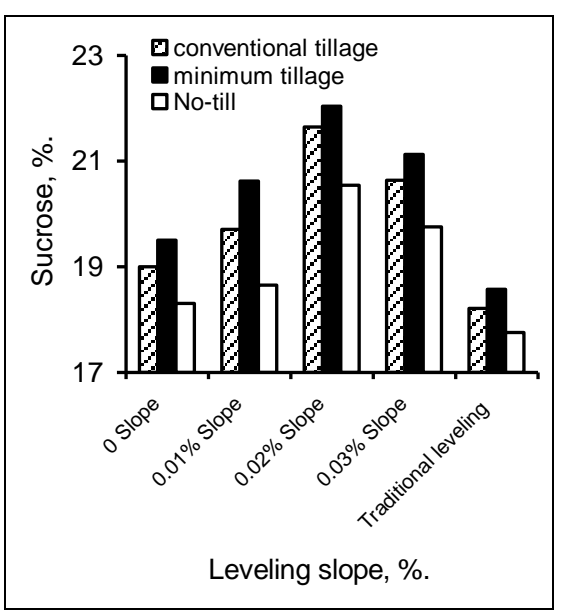

b. Sucrose.

Fig. (5): Effect of minimum tillage on beet and sucrose yield.

The conventional tillage achieved lower sugar beet and clover crop yield than that was obtained using the minimum tillage. It creats aggregated soil structure of higher relative penetration resistance and bulk density values. This structure is due to the frequent vehicles traffic which increases the soil compaction which reduced the depth of root penetration and proliferation. Also, this effect reduces the soil hydraulic conductivity. Hence, drainage of water to reach the field capacity required a longer period, and the soil infiltration rate decreases. These conditions lead to a poor development of roots because of restricting root penetration and proliferation.

On the other hand, the no-till of overly steep surface may result in poor surface drainage and muddy soil conditions, resulting in lower rate of plant establishment.

The analysis of variance test indicates that there was high significant difference in beet yield due to the precision leveling slope treatment and the tillage treatment. L. S. D. test shows that applying the precision land leveling at $0.02 \%$ slope and adopting the minimum tillage achieved the higher beet yield among the other treatments. 


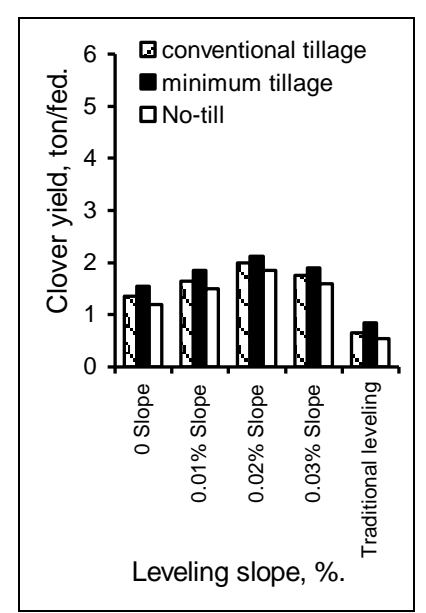

a. $1^{\text {st }}$ cut.

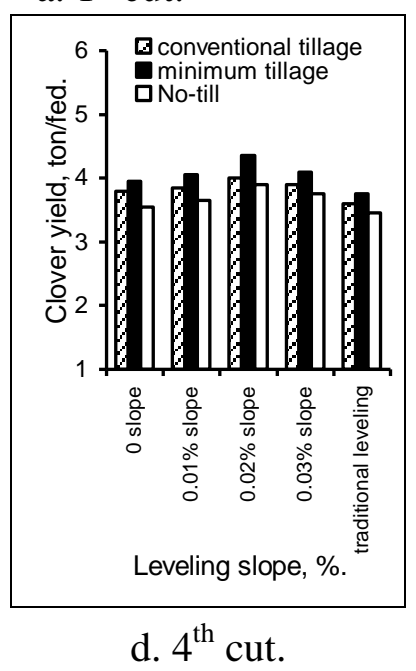

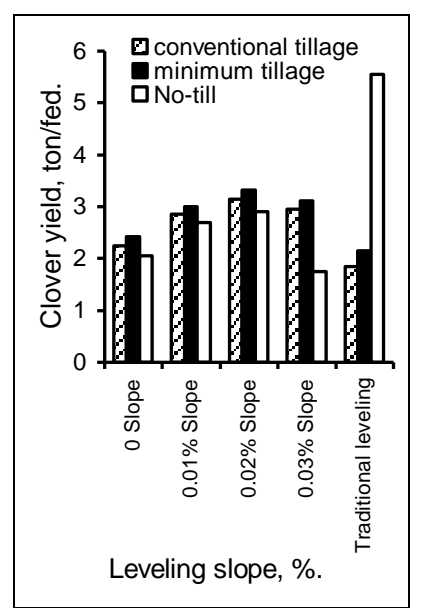

b. $2^{\text {nd }}$ cut.

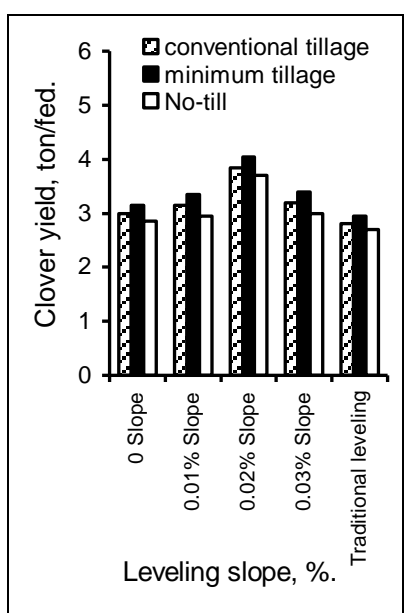

c. $3^{\text {rd }}$ cut.

Fig. (6): Effect of minimum tillage on dry clover yield.

The obtained data of the regression and correlation analysis reveal that there was a highly significant positive correlation between beet crop yield (y) and precision land leveling slope (x) as follows:

Conventional tillage: $y=-1.1000 x^{2}+6.3500 x+17.404 \quad\left(R^{2}=0.9513\right)$ Minimum tillage $: y=-1.3793 x^{2}+0.6067 x+18.3060 \quad\left(R^{2}=0.9660\right)$ No-till

$$
: y=-0.6429 x^{2}+3.9071 x+18.9200 \quad\left(R^{2}=0.6731\right)
$$

The analysis of variance test indicates that there was high significant difference in clover yield due to the precision leveling slope treatment and the tillage treatment. L. S. D. test shows that applying the precision 
land leveling at $0.02 \%$ slope and adopting the minimum tillage achieved the higher clover yield among the other treatments.

The obtained data of the regression and correlation analysis reveal that there was a highly significant positive correlation between total clover crop yield (y) and precision land leveling slope $(\mathrm{x})$ as follows:

Conventional tillage: $y=-0.9375 x^{2}+5.3422 x+8.0125 \quad\left(R^{2}=0.7191\right)$

Minimum tillage $: y=-0.1239 x^{2}+7.5010 x+9.5460 \quad\left(R^{2}=0.9682\right)$

No-till

$$
: y=-0.7125 x^{2}+4.2575 x+7.8625 \quad\left(R^{2}=0.8571\right)
$$

\section{CONCLUSION}

The obtained results of this study could be concluded as follows:

1. The minimum tillage at the precision land leveling slope of $0.02 \%$ achieved the more desirable soil characteristics, allowing releasing higher amount of available soil macronutrients.

2. It accomplished higher degree of soil topography conservation.

3. It achieved the higher beet yield of $28.65 \mathrm{Mg} /$ fed with a sucrose yield of $22.04 \%$ and complemented the higher total dry (14\% moisture content d.b.) clover yield of $17.10 \mathrm{Mg} / \mathrm{fed}(2.12,3.32,4.04,4.36$ and $2.87 \mathrm{Mg} /$ fed for $1^{\text {st }}, 2^{\text {nd }}, 3^{\text {rd }}, 4^{\text {th }}$ and $5^{\text {th }}$ cuts, respectively).

So, it is recommended to apply the minimum tillage, especially with the ridge planting, after rice harvest to conserve the precise leveled soil.

\section{REFERENCES}

Abd El-Aal, S.E.; A.M. Kishta and A. lotfy (2005). Seedbed preparation and irrigation depths affecting soil physical properties and rice yield. Misr J. Agric. Eng., 22 (2): 572-591.

Abd el-Mageed, H.N. (1989). Effect of compaction and tillage method on corn yield and physical properties of two soil types. Misr J. Ag. Eng., 6 (3): 224-236.

Abd El-WAhab, M.K.(1994). Minimum tillage by a simple combination. Misr J. Agric. Eng., 11 (1): 711-724.

Abu-Zaid, M. (1995). Efforts towards management of agricultural water demands. Proceedings of the $2^{\text {nd }}$ Conf. of On-farm irrigation and Agroclimatolgy, 2-4. 
ASAE standard: S296.4 (1992). Cubes, Pellet, and crumbles-definitions and methods for determining density, durability and moisture content, $384 \mathrm{pp}$.

Bahnas, O.T.; E.M. Arif and S.N. Abd El-Haleim (2009). Effect of precision land leveling, planting method and biofertilizers application on rice grain yield in sandy soils. J. Ag. Sci. Mansoura Univ., 34 (5): 5809-5822.

Blakeney, A.B. and L.L. Mutton (1980). A simple colorimetric method for the determination of sugars in fruit and vegetables. J. of the Sci. of Food and Agriculture, 31: 889-897.

El-Banna, E.B.; H.N. Abd El-Mageed and M.A. Helmy (1987). Tillage machinery and timeliness costs affecting soil structure, winter barley and sugar beet crop profits. Misr J. Agric. Eng., 4 (4): 415-435.

El-Raie, A.S.; A.M. El-Nozahy and R.K. Ibrahim (2003). Laser land leveling impact on water use efficiency, soil properties and machine performance under agricultural intensification conditions. Misr. J. Ag. En. 20 (4): 757-775.

El-Raie, A.S.; A.T.Imbabi; M.F. Hassan and K.A. Gabber (2004). Precision land leveling by using laser technology under the conditions of Fayoum Governorate. Misr J. Ag. Eng, 21 (2): 321-340.

El-Nakib, A.A. and H.A. Fouad (1990). Effect of minimum tillage with conditioner implement on soil physical properties. Misr J. Ag. Eng., 7 (2): 121-131.

El-Sahrigi, A.F.; S.L. El-Khatib and A.A. El-Bahery (2002). Effect of farming operations on the duration of laser technology precision land leveling for successive seasons. J. Ag. Sci., Ain shhans Univ., Cairo 10 (1):59-71.

El-Sayed, A.S. and F.S. Ismail (1994). Effect of different tillage techniques on some soil properties \& cotton yield. Misr J. Ag. Eng., 11 (4): 922-941.

EI-Serafy, Z.M. and A.M. El-Ghamry (2006). Methods of soil and water analysis (Practices), Soils Dept., Fac. Of Ag., Mansoura Univ., 253 pp. 
Kepner, R.A.; R. Beiner and E.L. Barger (1982). Principles of farm machinery., $3^{\text {rd }}$ Ed., The AVI Pup. Com. Inc. 527 pp.

Mc Clung, J.A.; S. Shepley; M. Ismail and M.N. Seif El-Yazal (1985). Mechanical and economical study of land leveling in Middle Egypt. Ag. Mech. Proj. Paper work No. 21.Ministry of Ag. ARE.

Mourad, S.A.; M.A. Ali; S.M. El-Awady and KH.A. Mowafy (2003), The roal of certain environmental factors on the population activity of rice leaf miner hydraulic prosternalis; deeming and leafhopper balclutha hortensis lindb, at the northern parts of Delta. J. Ag. Res., 81 (4): 1619-1629.

Nour, M.A.; A.E. Abd El-Wahab and F.N. Mahrous (1994). Effect of water stress at different growth stages on rice yield and contributing variables. Rice Res. and Training Center, Annual Agronomy Report.

Nour, M.A.; A.E. Abd El-Wahab; A.A. El-Kady and R.A. Ebaid (1997). Productivity of some rice varieties under different irrigation intervals and potassium level. J. Appl. Sci., 12 (6): 137-154.

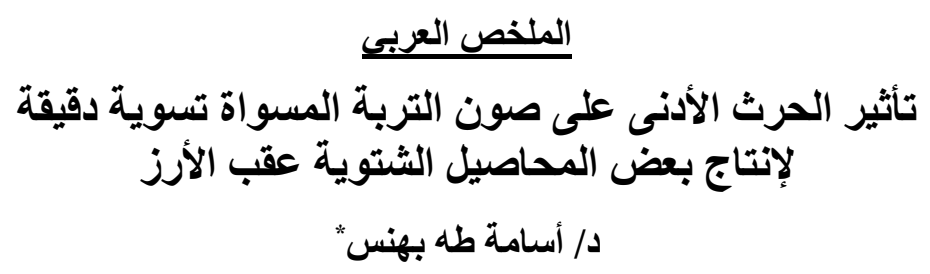

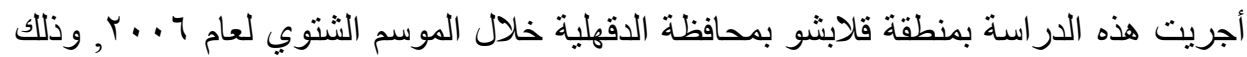

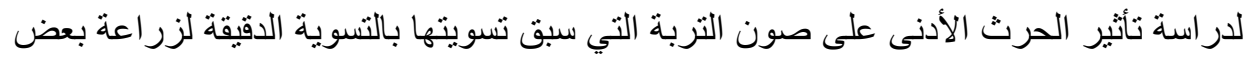

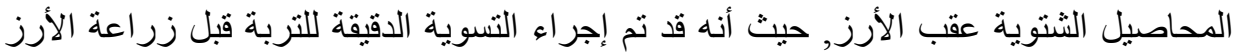

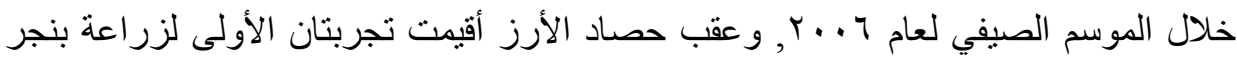

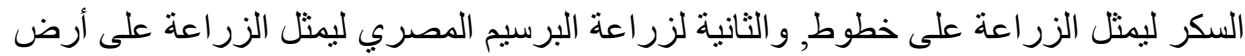

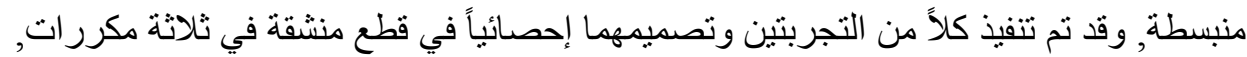

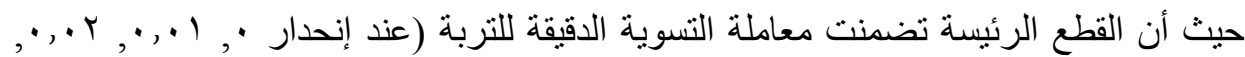

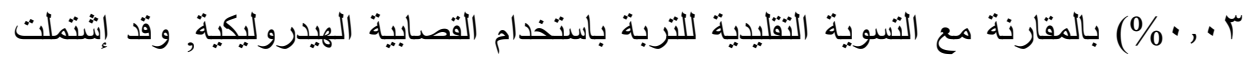

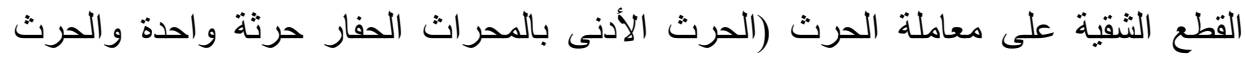

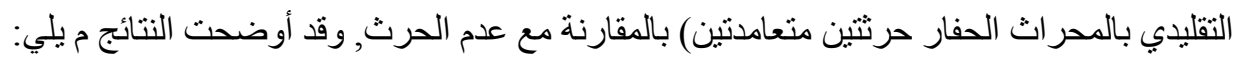

$$
\text { * باحث أول بمعهد بحوث الهندسة الزر اعية - مركز البحوث الزر اعية ـ الجيزة. }
$$


ا. . حقق الحرث الأدنى عند إنحدار r • , •\% عقب زر اعة بنجر السكر أفضل خصائص للتربة, حيث أنه حقى القيمة المتوسطة لقطر متوسط أوزان حبيبات التربة بمقدار 10 ممو أعلى

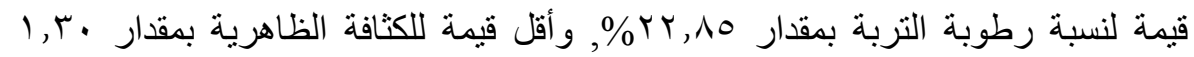

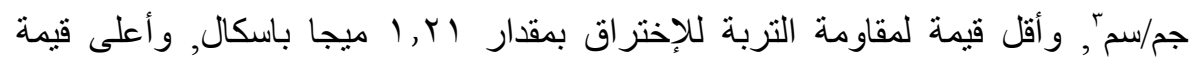

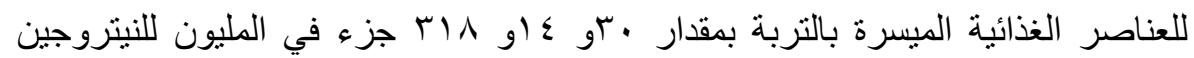
و الفوسفور و البوتاسيوم على الترتيب.

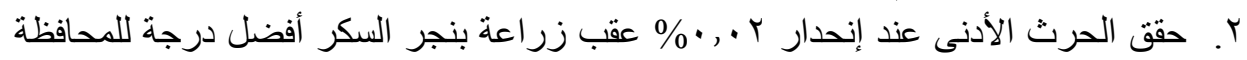
على طبو غر افية التربة حيث أنه قد أعطى أقل فرق بلين أعلى و أدنى أدنى منسوب للتربة.

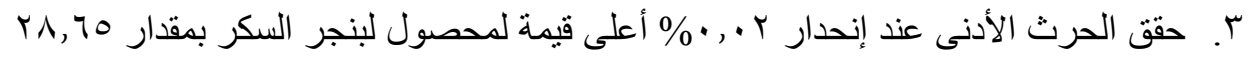

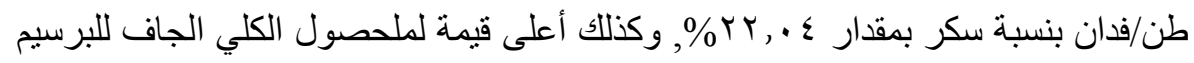

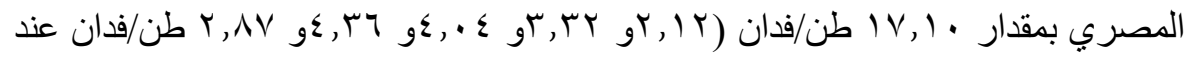
كل من الحشات الأولى و الثنية و الثالثة و الر ابعة و الخامسة على على الترتيب).

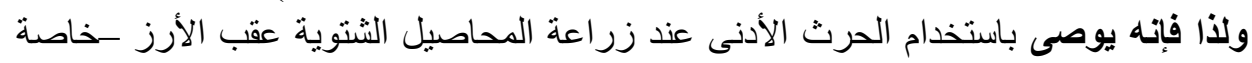
في حالة الزر اعة على خطوطـ لصون التربة التي سبق تسويتها بالتسوية الدقيقة. 